\title{
DNA barcoding of Podonomus (Chironomidae, Podonominae) enables stage association of a named species and reveals hidden diversity in Brazilian inselbergs
}

\author{
Susana Trivinho-Strixino ${ }^{1}$, Mateus Pepinelli ${ }^{1}$, Tadeu Siqueira ${ }^{2}$ and Fabio de Oliveira Roque ${ }^{3}$ \\ ${ }^{1}$ Laboratório de Ecologia de Insetos Aquáticos (LEIA), Departamento de Hidrobiologia, Universidade Federal de São Carlos, \\ São Carlos, Cx. Postal: 676, CEP 13565-905, SP, Brazil \\ 2 Departamento de Ecologia, Universidade Estadual Paulista, Avenida 24-A,1515, CEP13506-900, Rio Claro, SP, Brazil \\ 3 Centro de Ciências Biológicas e da Saúde, Universidade Federal de Mato Grosso do Sul, CCBS, Cidade Universitária, Caixa Postal \\ 549, CEP 79070-900, Campo Grande, MS, Brazil
}

Received 24 May 2012; Accepted 14 November 2012

\begin{abstract}
Podonomus Philippi was recently found in Brazilian inselbergs. In this study, we used sequences from the barcode region of cytochrome $c$ oxidase I (COI) to assess Podonomus molecular diversity from mountains in Southeastern Brazil. Our results revealed the adult female and the larvae of Podonomus pepinellii Roque and Trivinho-Strixino, 2004 and extended the known geographical distribution of the species. Moreover, we found high molecular divergence in two populations located in the Serra da Mantiqueira and Serra do Espinhaço mountain range when compared with the only species recorded to Brazil, indicating the possibility of two more species to be described.
\end{abstract}

Key words: Diptera / molecular identification / immature stages / cytochrome $c$ oxidase I

\section{Introduction}

DNA barcoding has advanced the identification and discovery of many taxa (e.g. Hebert et al., 2004; Hamada et al., 2010), including chironomid species (Ekrem et al., 2007; Ekrem et al., 2010; Stur and Ekrem, 2011). The taxonomy of some groups of Chironomidae has benefited from the use of DNA barcoding (Wiedenbrug et al., 2009; Laurindo et al., 2012), particularly those with morphological similarity or that are difficult to rear or obtain all associated stages, as some species in the genus Podonomus Philippi.

According to Cranston et al. (2010), Podonomus (Chironomidae: Podonominae) is a monophyletic genus and is sister to Parochlus Enderlein. Among the 40 valid species in this genus and nine morphotypes not formally described (Ashe \& O'Connor, 2009), pupae are known for 25 species (Brundin, 1966), whereas the larval stage is only known for two species: Podonomus albinervis Edwards and Podonomus fastigans Brundin, the first with occurrence in Argentina and Chile and the second in Argentina, Bolivia and Peru. The occurrence of the genus, so far, is restricted to the southern hemisphere, with records in the Andes and in the Brazilian Atlantic Rainforest (Brundin, 1966; Roque and Trivinho-Strixino, 2004). Most of the species live in very remote places (e.g. isolated hygropetric biotopes in high mountains), which makes difficult to keep these organisms alive when trying to rear them.

In this study, we sampled Podonomus in inselbergs located in the Atlantic Forest, in the Serra do Espinhaço mountain range and in the Serra da Mantiqueira mountain range (southeastern Brazil), most of them at elevations above $1500 \mathrm{~m}$ a.s.l. Using the DNA barcode region of the cytochrome $c$ oxidase I (COI) mitochondrial gene, we were able to associate the female and immature stages of Podonomus pepinellii Roque and Trivinho-Strixino, herein described. DNA barcoding also suggested the existence of hidden diversity within the genus.

\section{Material and methods}

\section{Sampling areas}

Larvae, pupae, males and females of Podonomus were sampled in eight sites in five inselbergs in four different states in Brazil (see Table 1).

Larvae and pupae were hand collected directly from the substrate (bedrock) under water with forceps and a 
Table 1. Sites of collection of Podonomus specimens in Brazil.

\begin{tabular}{|c|c|c|c|c|c|}
\hline Taxa (stage of life) & Site & State & Latitude & Longitude & Altitude, $\mathrm{m}$ \\
\hline P.pepinellii & Campos do Jordão & São Paulo & -22.7666 & -45.5208889 & 1815 \\
\hline P.pepinellii & Teresópolis & Rio de Janeiro & -22.4505 & -43.0138333 & 1581 \\
\hline P. pepinellii/Podonomus sp. & Caparaó & Espírito Santo/Minas Gerais & -20.4197 & -41.8461389 & 1276 \\
\hline Podonomus sp. & Caparaó & Espírito Santo/Minas Gerais & -20.4555 & -41.8088611 & 2258 \\
\hline Podonomus sp. & Caparaó & Espírito Santo/Minas Gerais & -20.4177778 & -41.8165556 & 2239 \\
\hline Podonomus sp. & Caparaó & Espírito Santo/Minas Gerais & -20.4314444 & -41.7988611 & 2743 \\
\hline Podonomus sp. & Caraça & Minas Gerais & -20.1061389 & -43.4613889 & 1727 \\
\hline P. pepinellii & Monte Verde & Minas Gerais & -22.886 & -46.0324722 & 1916 \\
\hline
\end{tabular}

small net. Larvae and pupae were preserved in absolute ethanol. Pharate adults were maintained alive in a covered plastic vial, with a piece of wet filter paper, to obtain the adults. The adults that emerged and the pupae with pharate adults that did not emerge were preserved in absolute ethanol.

\section{DNA barcoding}

DNA was extracted, amplified and sequenced following the protocols of the Canadian Centre for DNA Barcoding (http://www.ccdb.ca/pa/ge/research/protocols). We used part of the larvae (not including the digestive tract) removed from voucher specimens preserved in ethanol. In this study, we examined 75 specimens of the genus Podonomus (Table 1). For the samples, the primers LepF (5-ATTCAACCAATCATAAAGATATTG-3) and LepR (5-TAAACTTCTGGATGTCCAAAAAATC-3) amplified the target 658-bp fragment of COI. Sequences were obtained by using either ABI 377 or ABI 3730 sequencers (Applied Biosystems). Sequences were edited and assembled by using SEQUENCHER (Gene Codes, Ann Arbor, MI). Sequences were then aligned and edited manually. Sequence information was entered in the Barcode of Life Database (BOLD, www.boldsystems.org) along with an image and collateral information for each voucher specimen. The detailed specimen records and sequence information, including trace files, are available on the BOLD in the project files (Aquatic insects from Inselbergs in Brazil [MPBIM]). All sequences have been submitted to GenBank. Kimura's two-parameter model of base substitution (Kimura, 1980) was used to calculate genetic distances in MEGA 5 software (Tamura et al., 2011) and NJ trees were produced by using BOLD and MEGA 5 software.

\section{Taxonomy: terminology and abbreviations}

The terminology and abbreviations used in the descriptions follow Sæther (1980).

Larval head capsule size is given as the postmentum length measured from the tip of the mentum to the postoccipital margin. This measure is less susceptible to deformation during slide mounting than any "total" length. All measurements are given as ranges, the smallest measurement followed by the largest.

\section{Results}

Pieces of tissues from 75 specimens (larvae, pupae and adults) of the genus Podonomus were analyzed and sequenced. Successful amplifications of COI barcode gene were obtained for 39 specimens (Table 2). Amplification failed for 36 specimens.

Reared males collected from a population near to the type locality (Monte Verde, Table 1) were morphologically identified as $P$. pepinellii and all the other stages (larva and female) were associated using both morphology and DNA barcoding approach. We were not able to find more specimens in the type locality as it is mentioned in the last section of this article.

Analysis of DNA barcodes proved effective for the identification of $P$. pepinellii from four different areas in Brazil (Table 1) and indicated two additional very distinct groups - represented by one population collected in the Espinhaço mountain range (Caraça - cluster 1) and the other in the Mantiqueira mountain range (Caparaó National Park - cluster 2). Both populations showed high molecular divergence when compared with $P$. pepinellii populations (Fig. 1). Maximum intraspecific genetic divergence was $1.13 \%$ within $P$. pepinellii $(n=26)$ species, $2.5 \%$ within cluster 2 (Caparaó, $n=7$ ) and only $0.3 \%$ within cluster 1 (Caraça, $n=5$ ). Among the three distinct groups formed, the minimum interspecific distance between $P$. pepinellii and cluster 1 was $10.3 \%$, between $P$. pepinellii and cluster 2 was $7.6 \%$ and between cluster 1 and cluster 2 was $10 \%$. Ekrem et al. (2007) studied 47 species of Chironomidae and found a maximum pairwise distance within the tribe Tanytarsini was $25 \%$ (mean $16.2 \%$ ) and up to $4.9 \%$ within species (mean $0.87 \%$ ).

\section{Description}

P. pepinellii Roque and Trivinho-Strixino, 2004

Material examined: five females (N1-01 LEIA/ UFSCar; N1-02 LEIA/UFSCar; N1-03 LEIA/UFSCar; N1-04 LEIA/UFSCar; N1-05 LEIA/UFSCar), two males (N1-06 LEIA/UFSCar; N1-07 LEIA/UFSCar), four 


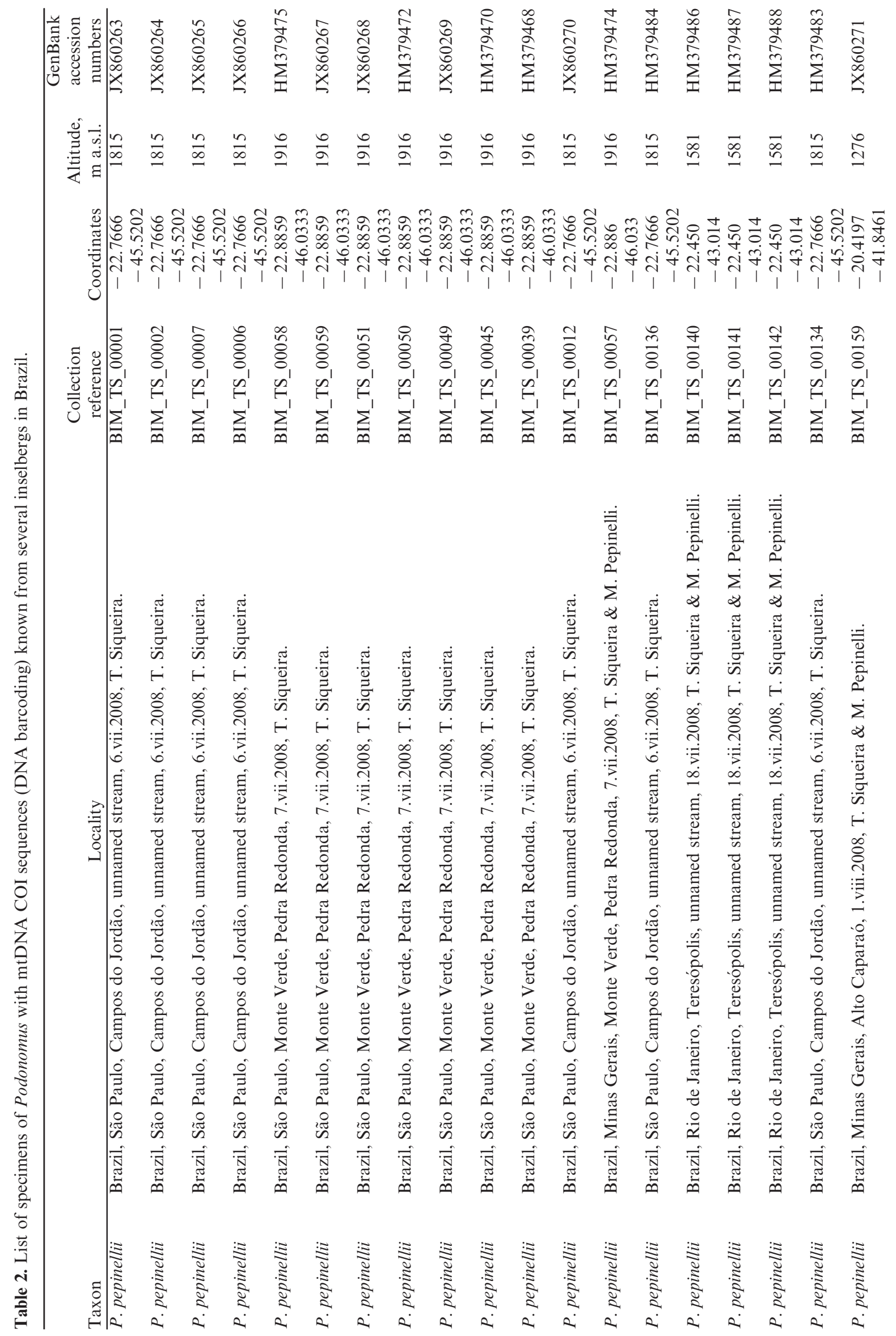




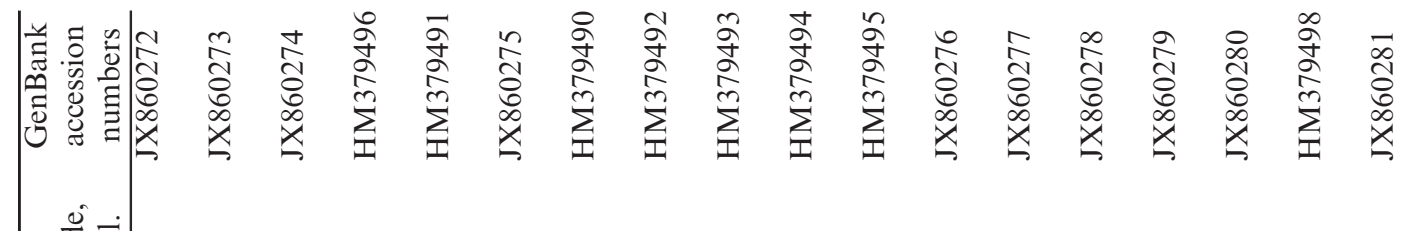

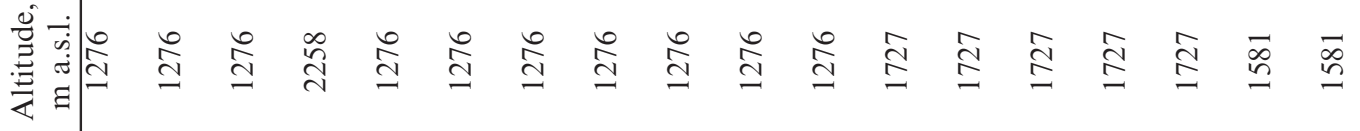

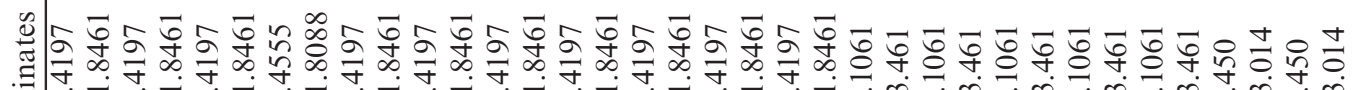

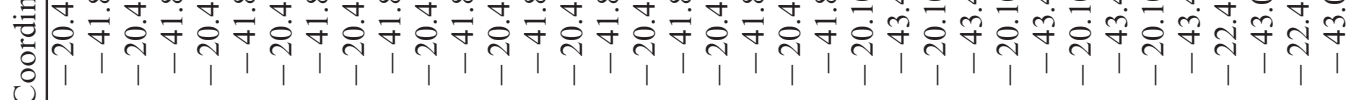

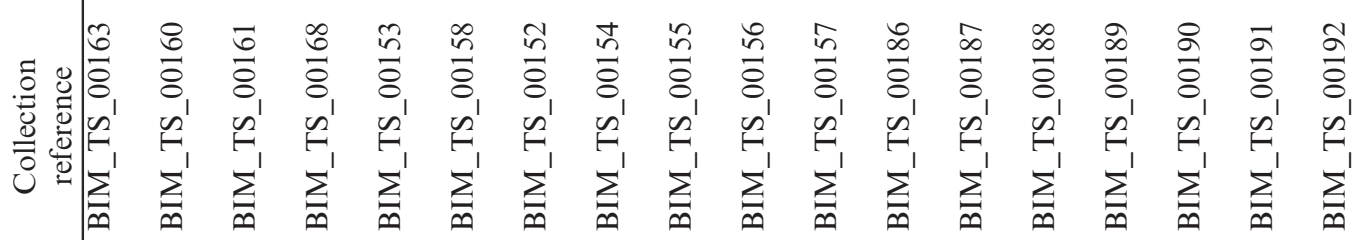

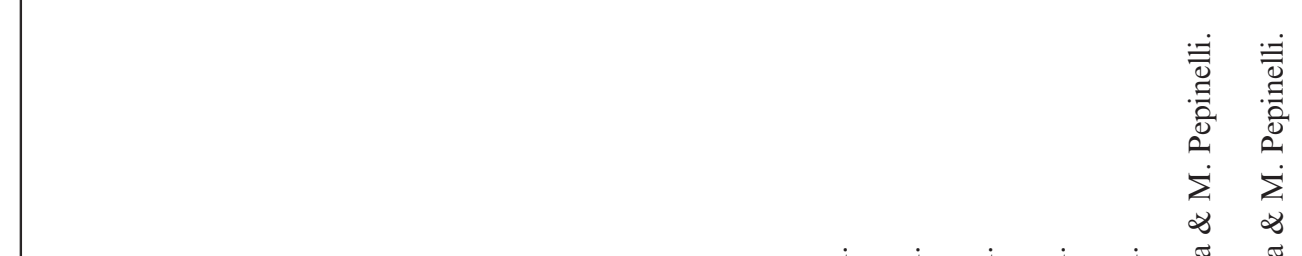

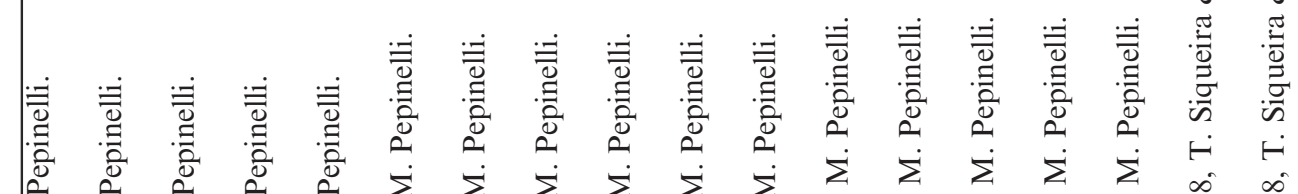

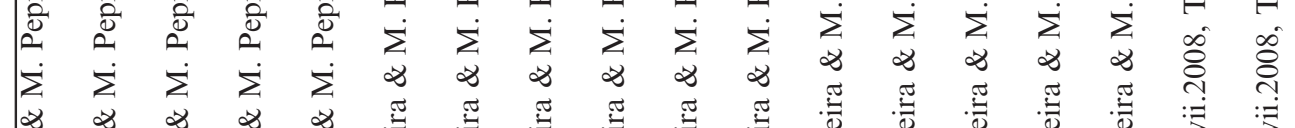

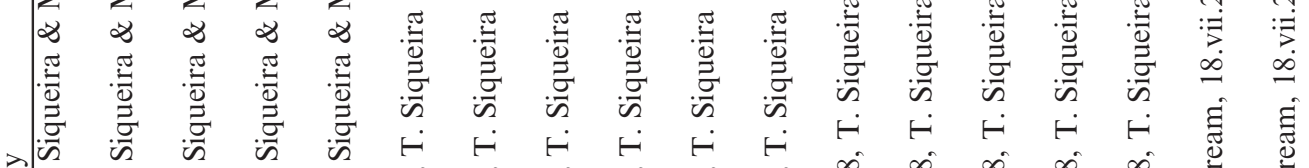

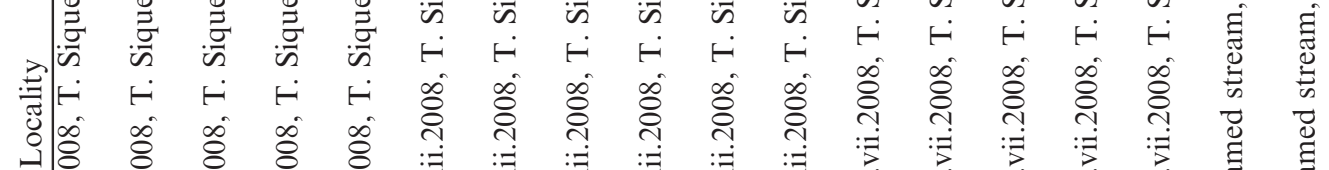

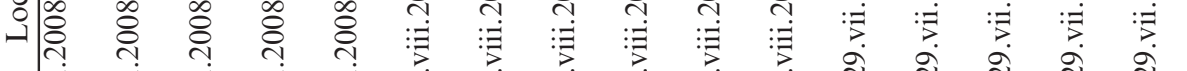

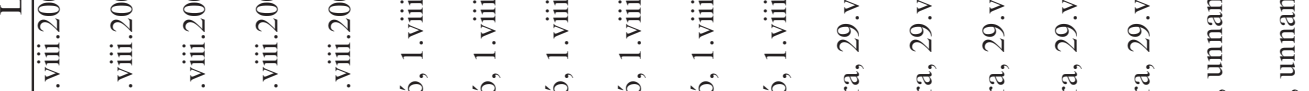

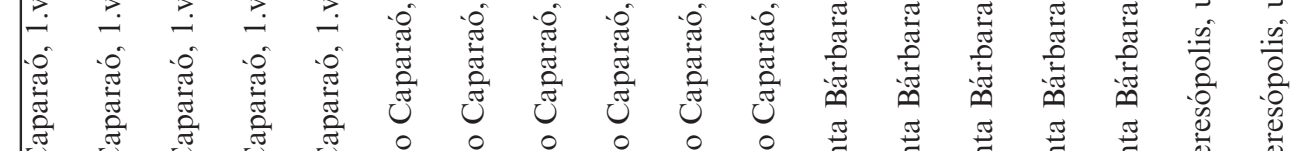
苟

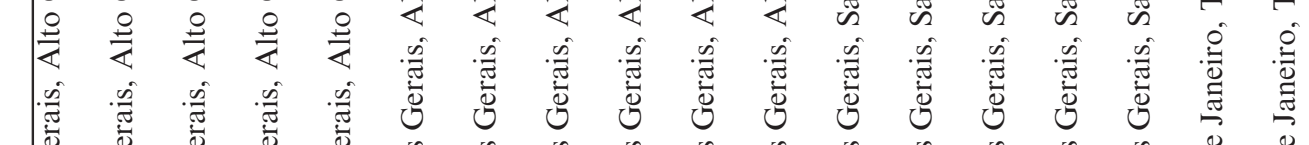

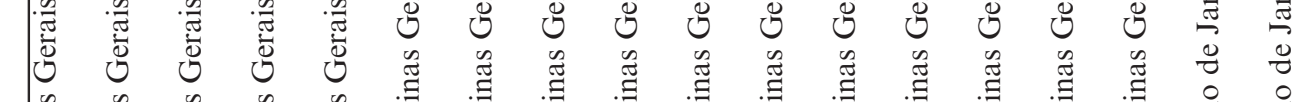

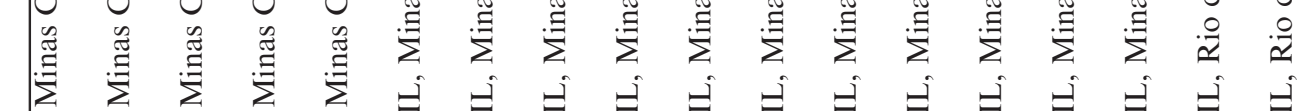

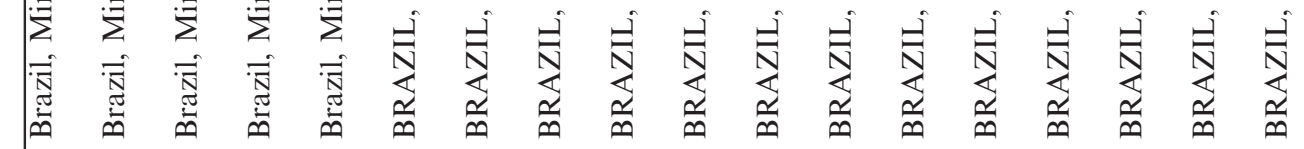

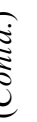

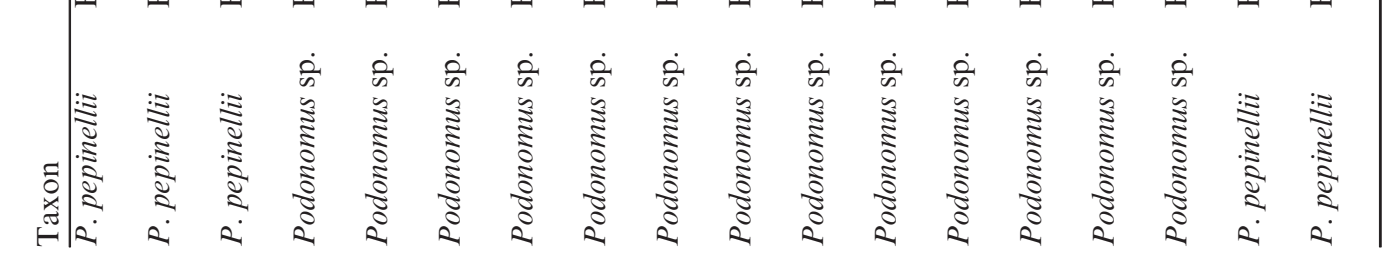




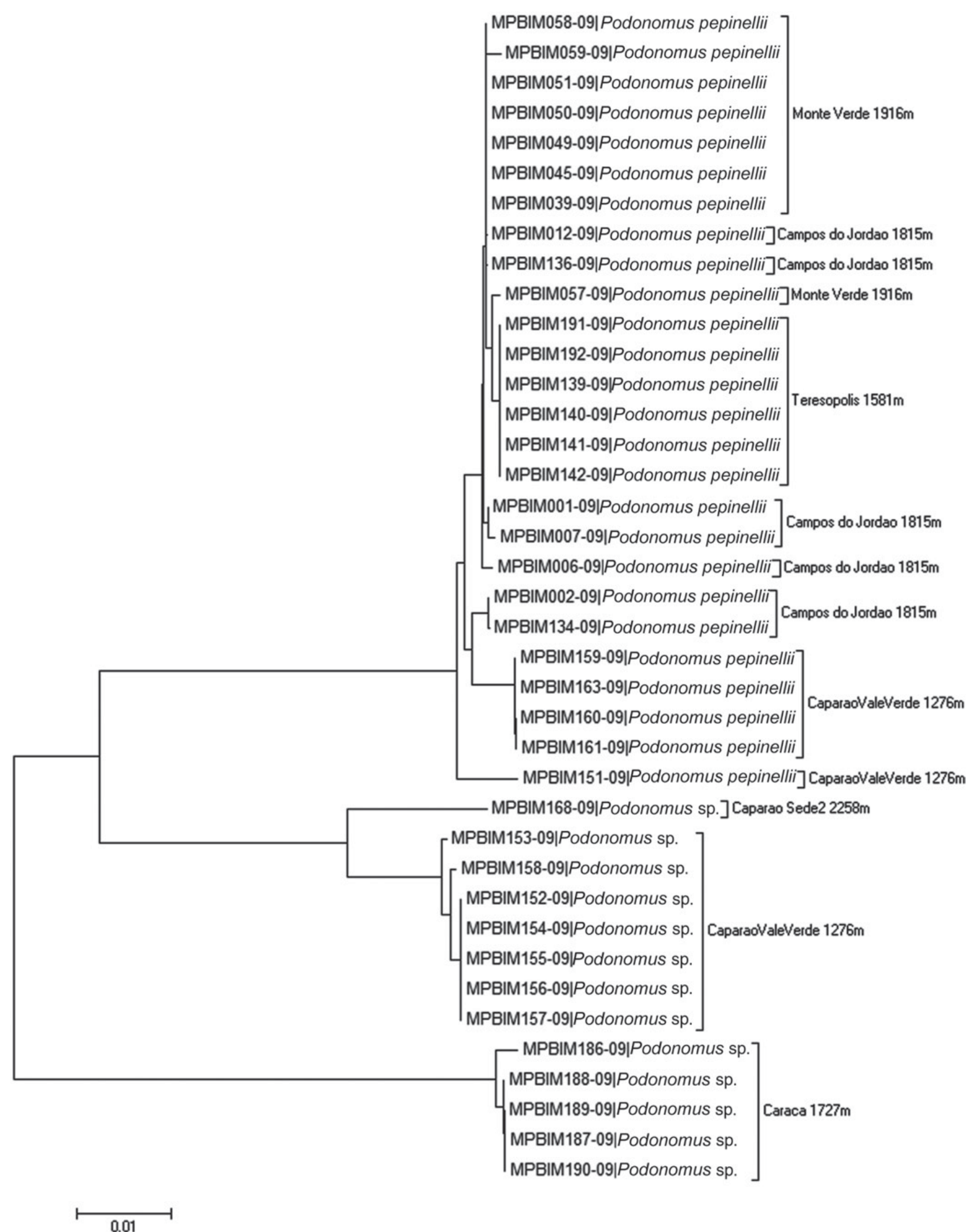

Fig. 1. Kimura 2-parameter neighbor-joining tree species of Podonomus sp.

larvae (N1-09 LEIA/UFSCar; N1-10 LEIA/UFSCar; N1-11 LEIA/UFSCar, N1-12 LEIA/UFSCar), one male and one female in the same slide (N1-08, LEIA/UFSCar), all in the same locality: Minas Gerais, Monte Verde,
Camanducaia, 21. Viii. 2004, leg. F. O. Roque. "UFSCar" is the hosting institution that means Universidade Federal de São Carlos and "LEIA" is the Laboratório de Ecologia de Insetos Aquáticos. 

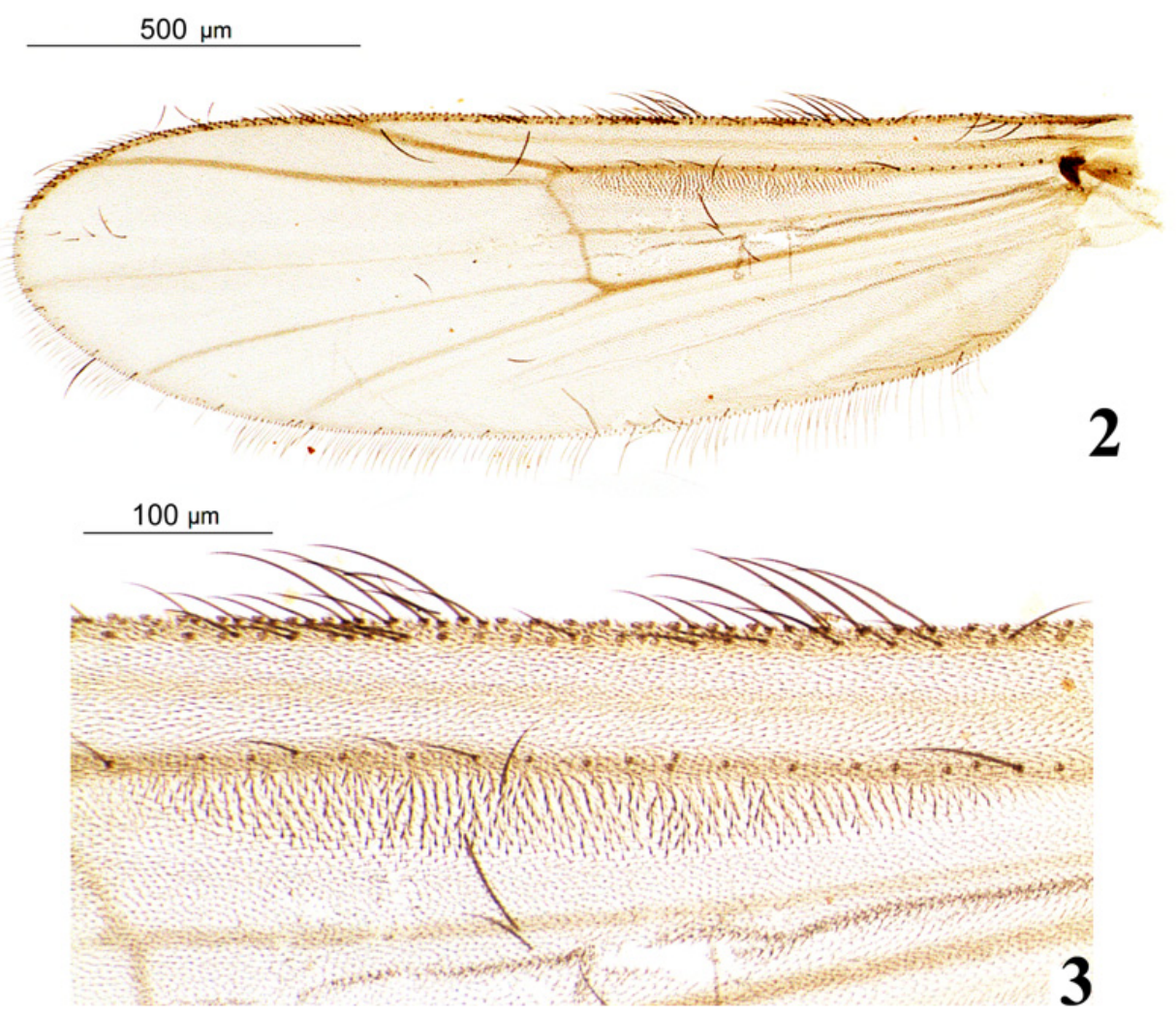

Figs. 2-3. P. pepinellii male (hototype). 2. Wing. 3. Detail of the wing showing the patch of stronger setae located in the posterior margin of the "r" cell.

Two additional labels with the collection code were added to the holotype of $P$. pepinellii, previously described by Roque and Trivinho-Strixino (2004), with the following codes: N1-13 LEIA/UFSCar (male) and N1-14 LEIA/ UFSCar (pupal exuviae associated). Additionally, we also included here some complementary information about the wing of male as follow.

Male $(n=2)$ : Wing with a group of short perpendicular setae forming a kind of darker cloud in the posterior margin of the " $r$ " cell, stronger than the microtrichia that covers the whole wing, as seen in Figures 2 and 3 (taken from the holotype N1-13 LEIA/UFSCar).

Female $(n=4)$. Body robust; wing $1384 \mu \mathrm{m}(1338$ 1415) long; $589 \mu \mathrm{m}$ (569-600) wide. VR=1.02. Head, thorax and abdomen color dark-brown; wings grayish; legs brownish.

Head. Temporal setae 10, clypeus four setae. Antenna $312 \mu \mathrm{m}$ long (286-336), with 10 flagellomeres, distal flagellomere larger, $62 \mu \mathrm{m}$. Palpomeres lengths 1-4: 41; $89,66,80 \mu \mathrm{m}$.

Thorax (Fig. 4). Acrostichals about 36, biserial; dorsocentral (Dc), humeral $(\mathrm{H})$, prescutellar $(\mathrm{Pr})$ and prealar (Pa) setation as in Figure 4; scutellars 5; postnotals absent.

Leg lengths and proportions in Table 3. Spur (Fig. 5) lengths: PI 37; PII 22, 34; PIII 34, $63 \mu \mathrm{m}$. Comb of hind tibia with 10 spiniform setae.

Wing (Fig. 6). Membrane without setae, except one or two on membrane between $\mathrm{Cu}_{1}$ and $\mathrm{M}_{3+4}$, and with microtrichia. Length $1384 \mu \mathrm{m}$ (1338-1415); width $589 \mu \mathrm{m}$
(569-600) $\mathrm{VR}=0.92-1.02 . \quad$ Vein seta: brachiolum $=2$; $\mathrm{R}=6-7 ; \mathrm{R} 4+5=5-7 ; \mathrm{M}_{1+2}=12 ; \mathrm{M}_{3+4}=4-5 ; \mathrm{Cu}_{1}=$ $0-1 ; \mathrm{R} 1=12-18 ;$ squama $=5$. Costa extended $18 \mu \mathrm{m}$ beyond apex of $\mathrm{R} 4+5$.

Genitalia (Figs 7-10). Tergite IX with about 15 setae. Gonotergite IX with numerous distal setae, the four laterals longer. GpVIII simple with microtrichia in all extension. Posterior margin of SX with several large setae partially covering the genital opening (Figs 8 and 10). Notum two times as long as free rami. Seminal capsules ovoid near $30 \mu \mathrm{m}$ long, without neck. Spermathecal duct slightly curved (Fig. 8). Postgenital plate triangular, very large, near $92 \times 100 \mu \mathrm{m}$; cercus nearly rectangular, $120 \mu \mathrm{m}$ long with three long setae distally and one shorter laterally (Figs 7 and 9).

4th instar larva $(n=4)$.

Larvae short: total length $3.36 \mathrm{~mm}$ (2.85-3.84), with brownish coloration, darkened dorsally with the anterior part near the head lighter (Figs 22 and 23). Head capsule dark brown, with white ring around dorsal cephalic setae and with one large eye-spot on each side. Head somewhat triangular, wider in its posterior part, width max. $274 \mu \mathrm{m}$ (253-290), dorsal length $296 \mu \mathrm{m}$ (267-320), ventral length $186 \mu \mathrm{m}$ (183-189).

Antenna (Fig. 11). With four segments without annulations; basal segment $36 \mu \mathrm{m}$ (37-37) longer than flagellum $22 \mu \mathrm{m}(21-23)(\mathrm{AR}=1.64)$; antennal blade $19 \mu \mathrm{m}$ (18-20) long; accessory blade as long as antennal blade. 


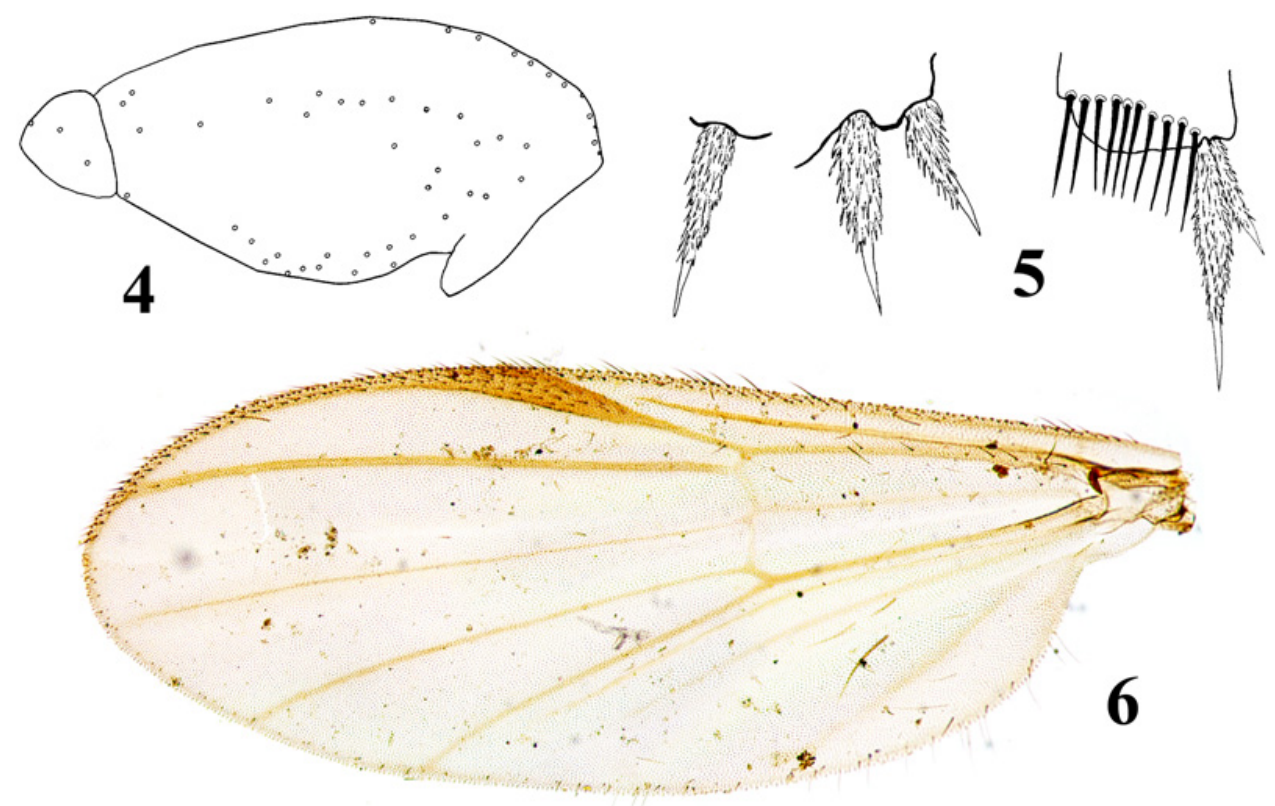

Figs. 4-6. P. pepinellii female. 4. Thorax, lateral view. 5. Tibial spurs of anterior, mid and posterior legs. 6. Wing.

Table 3. Leg measurements (in $\mu \mathrm{m})$ and ratios of $P$. pepinellii female $(n=4)$.

\begin{tabular}{lrrrrrrrr}
\hline & $\mathrm{fe}$ & $\mathrm{Ti}$ & \multicolumn{1}{c}{$\mathrm{ta} 1$} & $\mathrm{ta} 2$ & $\mathrm{ta}$ & $\mathrm{ta} 4$ & ta5 & LR \\
\hline PI & 437 & $394-450$ & $186-206$ & $125-137$ & 75 & $44-50$ & $56-75$ & $0.46-0.47$ \\
PII & 525 & $450-550$ & $206-225$ & $112-125$ & 75 & $37-38$ & $62-68$ & $0.41-0.46$ \\
PIII & $531-556$ & $500-562$ & $231-237$ & $144-175$ & $81-94$ & $44-56$ & $56-69$ & $0.42-0.46$ \\
\hline
\end{tabular}

Labrum. Labral setae and clypeal S3 as in Figure 12.

Mandible (Fig. 13). Measuring $93 \mu \mathrm{m}$ (90-94) in length, with outer margin strongly bent in middle, with seven teeth, one slightly small subapical outer, one large apical and five small inner teeth.

Mentum (Fig. 14). With $63 \mu \mathrm{m}$ (61-65) in width and 15 teeth brownish, seven median teeth light brown.

Prementum (Fig. 16). Localized behind the mentum, with a Y-like $\mathrm{M}$ appendage connected with 10 apicolateral paramedian lamellae (one median pair unicuspid, two lateral pairs bicuspid and two outer pairs palmate).

Body. Abdomen with many long brown single setae and short setal tufts in all segments. Procercus dark brown, $105 \mu \mathrm{m}$ (100-120) long, bearing seven strong apical dark setae (Figs 15, 17 and 18). Posterior parapods $309 \mu \mathrm{m}$ (294-320) long with a middle segmentation (Fig. 18); claws of two types, dark brown distributed in two rows (Fig. 19). Anal tubules short, $140 \mu \mathrm{m}$ (125-150) long.

\section{Discussion}

\section{Taxonomy}

The presence of stronger setae in the " $r$ " cell of the wing of the male of $P$. pepinellii was not reported in other known Podonomus species. Although we were searching for more information about this structure, we found an illustration in Brundin (1966, fig. 49, page 127) that seems very similar to that found in the wing of $P$. pepinellii (Figs 2 and 3). Brundin described it as a "detail of the anterior basal cell of the wing of Parochlus conjungens Brundin 1966", a species of another genus of the subfamily Podonominae. Apparently the size and distribution of those setae in the wing of $P$. pepinellii and $P$. conjungens are similar. However, the position of this patch of setae in the wing might not be the same between both species, although we have not found any information about what Brundin considered the "basal cell of the wing".

The Podonomus groups proposed by Brundin (1966) are mainly based on combination of morphological characters of male, female and pupae. Recently, Cranston et al. (2010), studying relationships among Gondwanian chironomids based on molecular and morphological approaches, including specimens of albinervis and decarthrus groups from South America, find support for the monophyly of albinervis group and suggest that decarthrus may be weakly paraphyletic.

According to Roque and Trivinho-Strixino the male and pupa of $P$. pepinellii does not fit readily into any of the Brundin's species groups. The absence of any trace of a subapical lobe on the gonostylus places the adult male in the albinervis group, but placement in this group is 

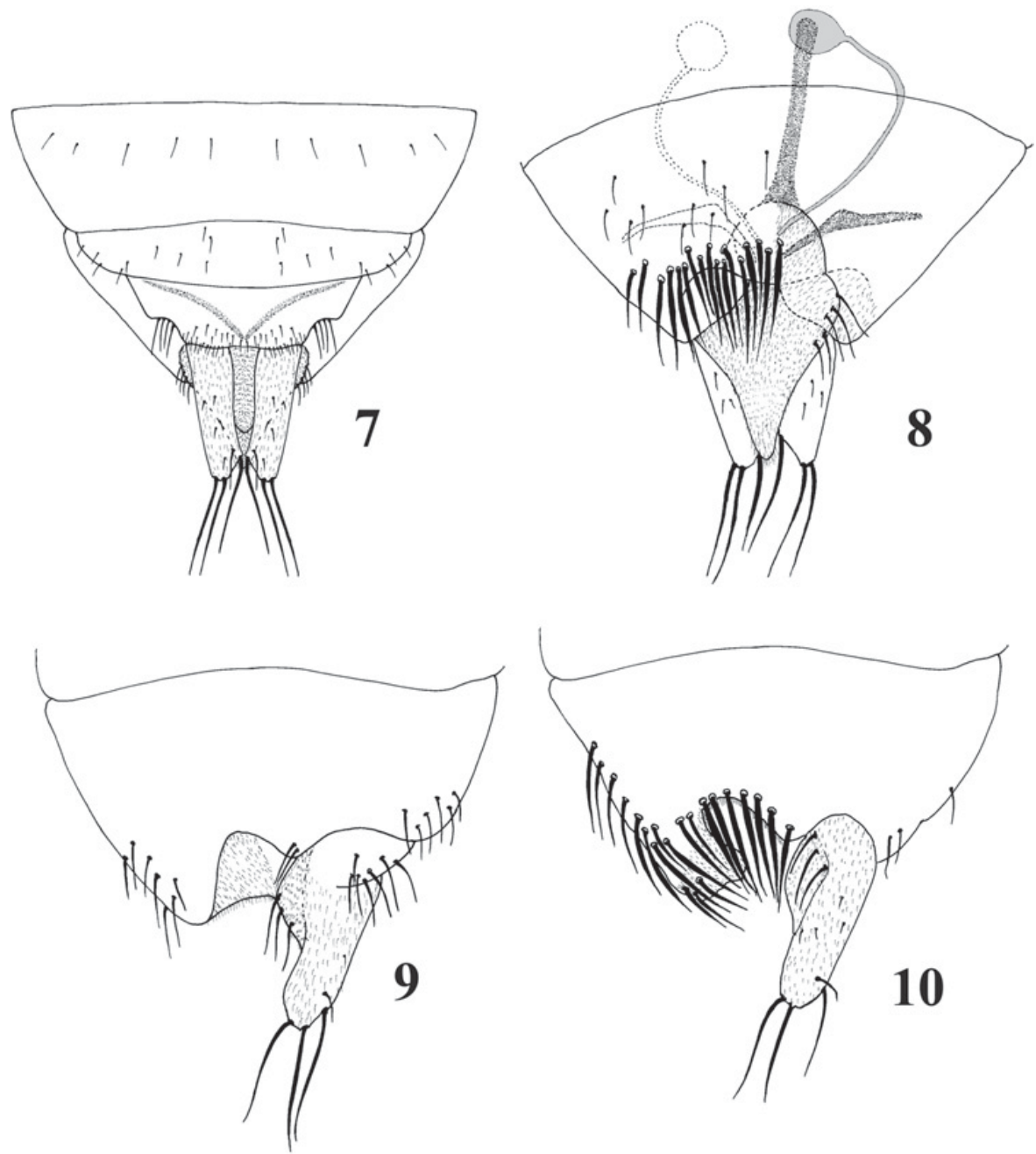

Figs. 7-10. P. pepinellii female. 7. Genitalia, dorsal view. 8. Genitalia, ventral view. 9 and 10. Genitalia, lateral view.

ruled out by the shapes of the pupal thoracic horn and posterolateral processes on abdominal segment VII. The pupal morphology appears most similar to that in Brundin's decarthrus group, but abdominal segment IX carries only five (rather than six or more) lateral macrosetae. Although, it is clear that more material and a more detailed phylogenetic analysis are needed to evaluate the validity of Brundin's species groups and the relative position of $P$. pepinellii, two characteristics of $P$. pepinellii here described add more pieces to the puzzle: shape of female cercus and lamella on pupal sternite II (missed in the holotype).

The presence of lamella on sternite II in the pupae of $P$. pepinellii is a conspicuous characteristic among species belonging to nudipennis and albinervis groups. The female of $P$. pepinellii has distinctive genitalia. Comparing with the all illustrations available from females of other Podonomus species (see figs 214-237 in Brundin 1966), only $P$. apolobambae Brundin presents some similarity to $P$. pepinellii in the shape of the cerci, differing by the number of setae (four long setae in the first, and only three in the latter) as seen in Figures 9 and 10. The shape and the number of distal setae of the cerci differentiate
$P$. pepinellii completely of those known species included in the nudipennis group and also in the decarthrus, albinervis and maculatus groups. Additionally, females of podonomines are poorly known and rarely described in detail.

The larva of $P$. pepinellii conforms to the diagnosis and description of the very few larvae that Brundin (1966) mentioned. The differential diagnosis of $P$. pepinellii larva is difficult due to the lack of other completely described Podonomus larvae. Recently Siri et al. (2009) described the larva of $P$. fastigans Brundin that can be distinguished from the larva of $P$. pepinellii by the following characters: mandible with four teeth (seven in $P$. pepinellii) and mentum with 17 teeth, instead of 15 in $P$. pepinellii.

All the larvae collected in Brazilian Inselbergs are morphologically very similar. The specimens collected from Caraça and Caparaó sites (Table 1) are represented only by immature stages. We have previously identified them as $P$. pepinellii, because there are no morphological differences at these stages among the populations studied. Analyses of the barcoding results showed at least two genetic divergent populations that need to be investigated (Fig. 1). Although the study of larval morphology did not bring evidence supporting the existence of several species 

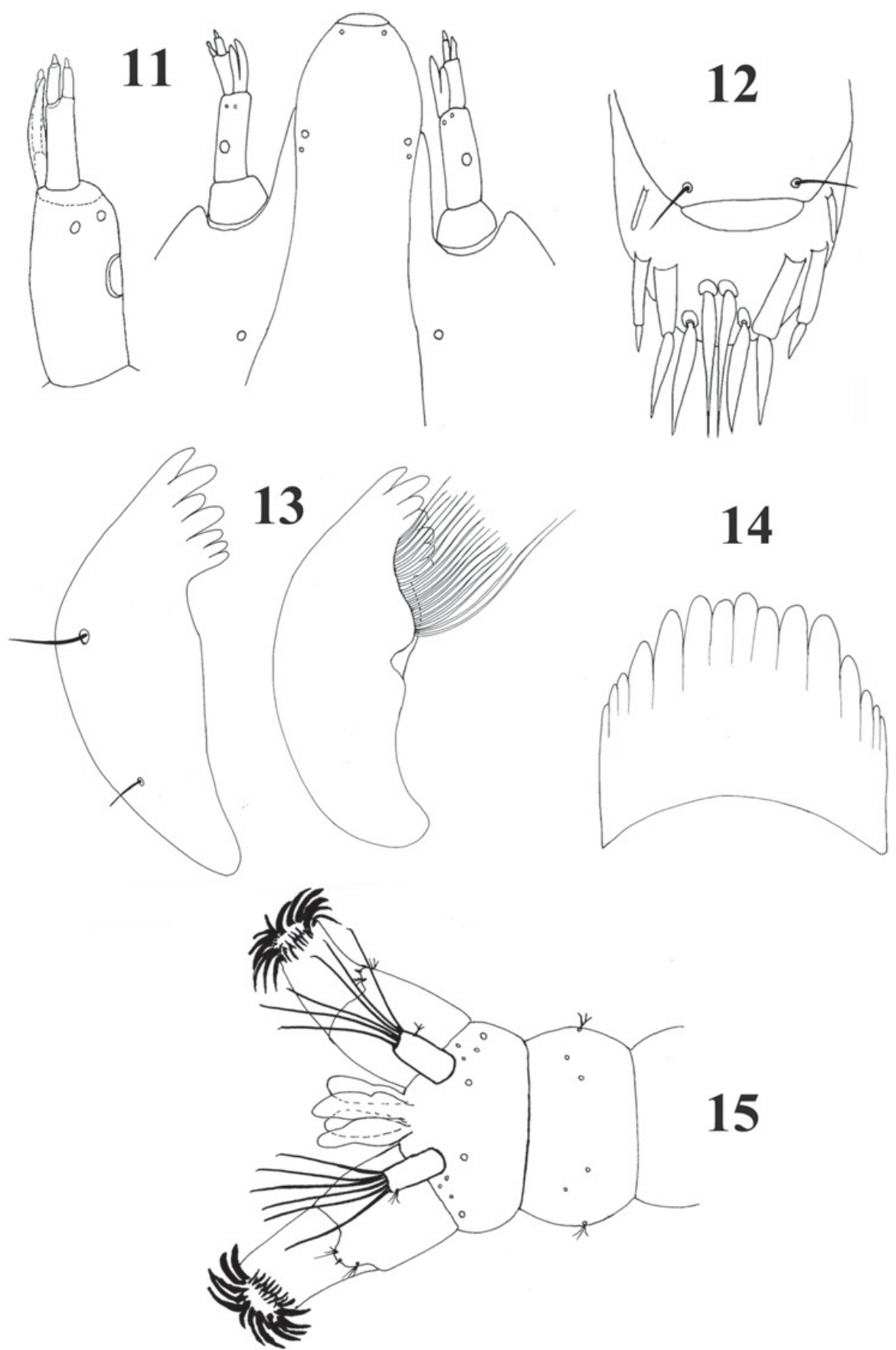

Figs. 11-15. P. pepinellii larva. 11. Antenna and anterior view of frontalclypeal apotome. 12. Labrum. 13. Mandible, dorsal and ventral view. 14. Mentum. 15. Posterior abdominal parapods, procercus, and abdominal tubules.

as the COI barcode gene region analyses did, there is still the need to search differences in adults.

This is a very interesting result, not only in terms of taxonomy but also in terms of making revealing diversity of species hidden by seemingly morphologically identical life stages. This is similar to recent efforts made by Chironomid experts such as Stur and Ekrem (2011), who used DNA barcoding as a tool to explore unknown life stages of Arctic Tanytarsini, and Ekrem et al. (2010) who showed that studying females of midges collected in traps using a DNA barcoding approach, besides the traditional taxonomic studies on males, increased the diversity of species in determined location by $27 \%$. Our results point to DNA barcoding as a very useful complementary taxonomic tool with great potential to help and elucidate new possibilities to advance our knowledge about biodiversity.

\section{Remarks, bionomics and distribution}

All immature stages of Podonomus were collected in hygropetric habitats (Figs 20 and 21). The larvae (Figs 22 

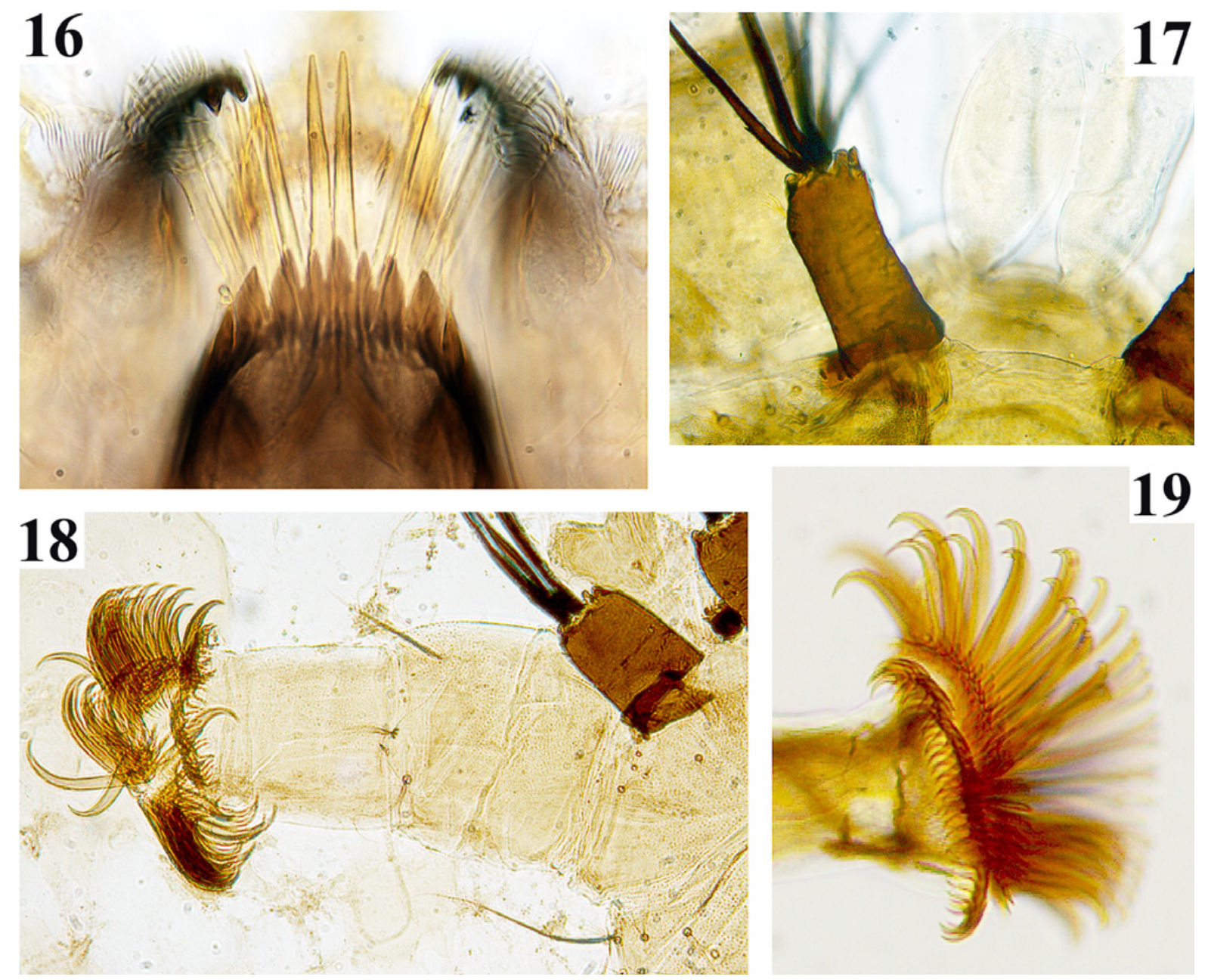

Figs. 16-19. P. pepinellii larva. 16. Mentum and paramediam lamellae of prementum. 17. Procercus and anal tubules. 18. Posterior abdominal segment and parapods. 19. Posterior parapod claws.

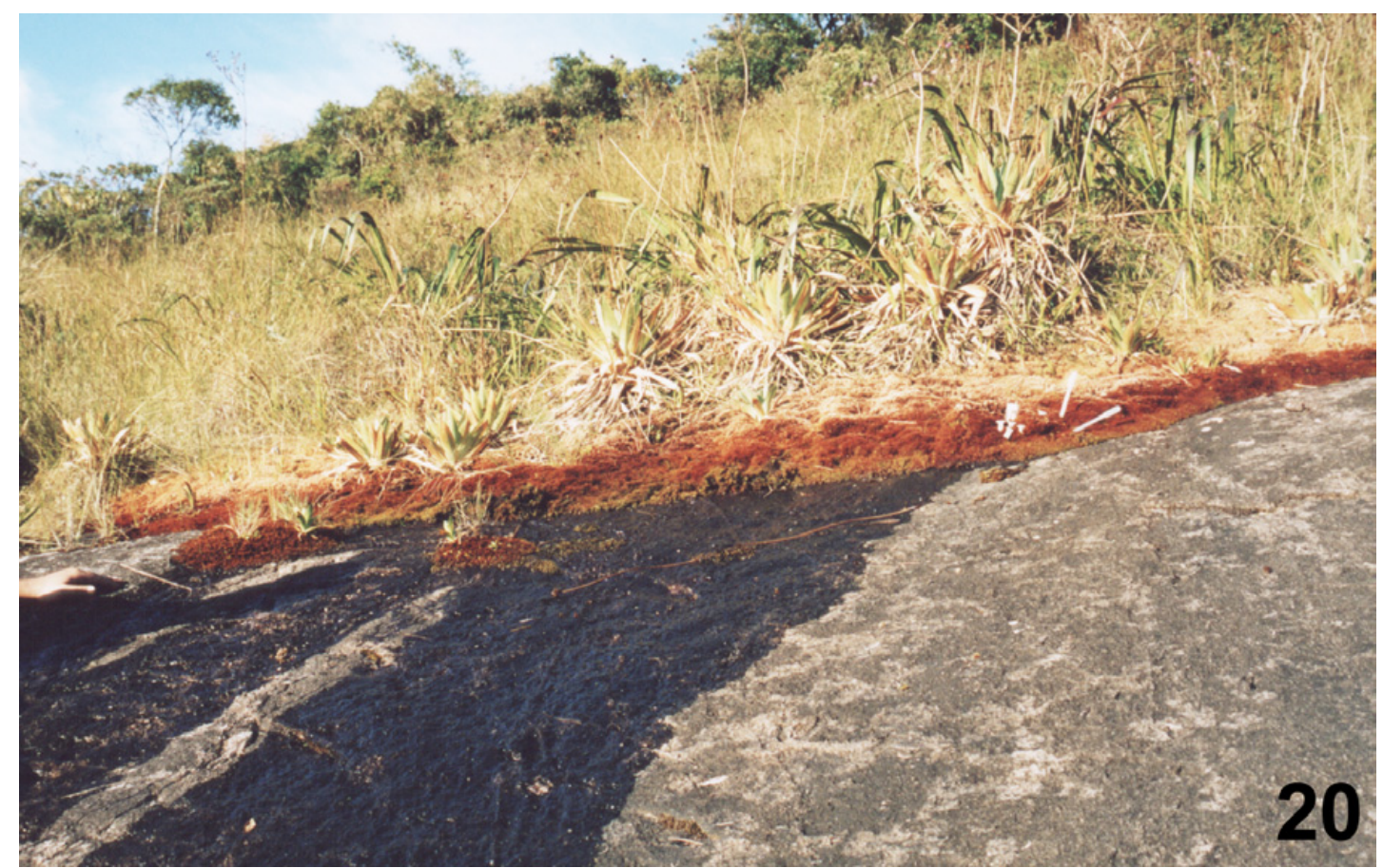

Fig. 20. Hygropetric habitat located in Monte Verde, Minas Gerais in the top of the Inselberg called "Pedra Redonda". 


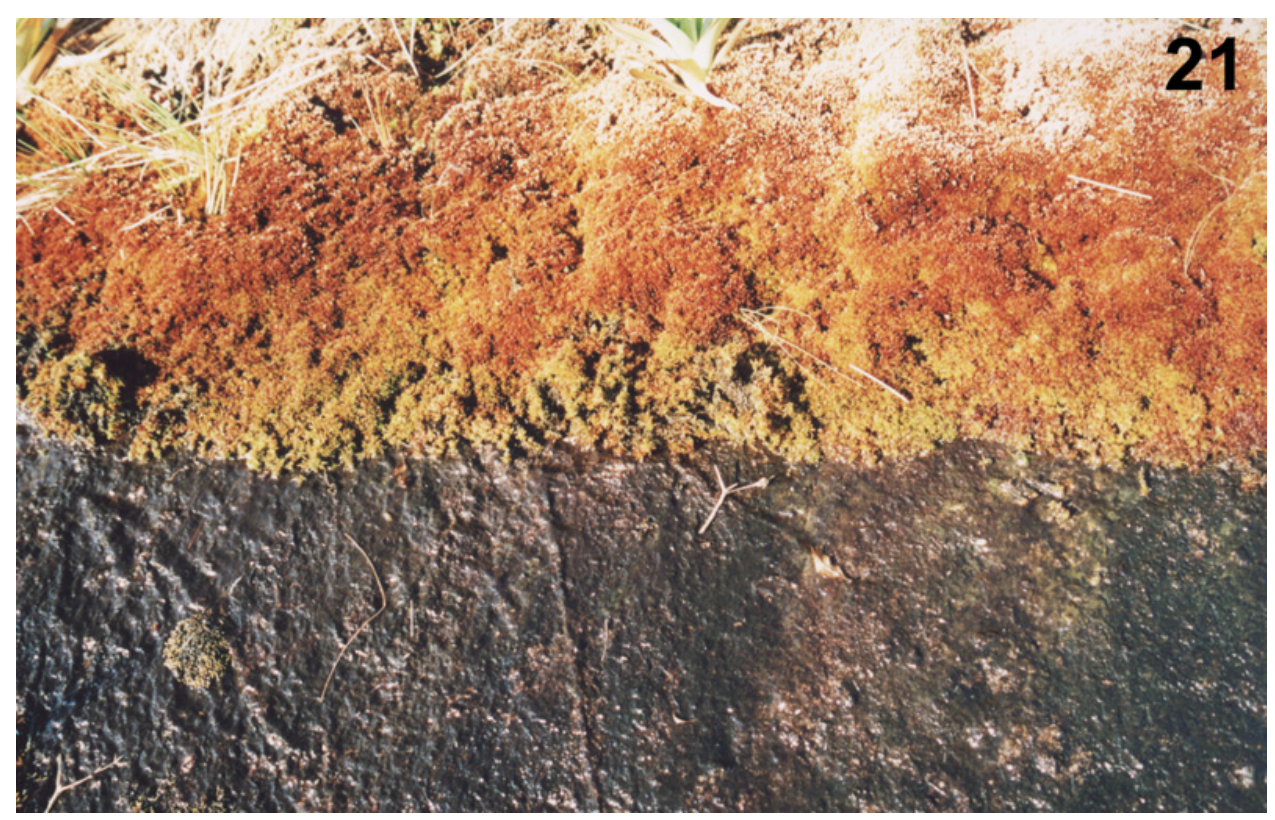

Fig. 21. Close view of the hygropetric habitat, showing the moss and the thin layer of water.

and 23) live upside down in a thin layer of water that runs slowly in the bedrock. They keep themselves attached to the substrate using the posterior parapods. They move laterally and horizontally using both posterior and anterior parapods. Pupae were found free in the water layer, inside moss and underneath moss (between the moss and the bedrock). As we have found more pupae inside or underneath moss, apparently prepupal larvae move towards areas near patches of moss, where they are able to get more protection during the pupal stage.

True $P$. pepinellii was collected in four localities (Table 1). The only known record was from a stream where the holotype was collected and described (see Roque and Trivinho-Strixino, 2004), located in Monte Verde, Minas Gerais State. We have visited the type locality several times, but have not found any more specimens in the hygropetric (wet rock surface) habitats at the margin of the low-order stream. However, we have found a large population of $P$. pepinellii living in a exposed rock in another site about $300 \mathrm{~m}$ away from the type locality in the same municipality in the top of an inselberg called "Pedra Redonda" - few metres higher from the mentioned stream (see Figs 20 and 21). Although we do not have topotypic fresh specimens of $P$. pepinellii, we did succeed in getting DNA from the population cited above, where we were able to compare morphologically several adult males with the holotype, and thus we are $100 \%$ confident that we have associated $P$. pepinellii with molecular diagnosed specimens.

The potential two different species of Podonomus were collected in another three sites from two different regions (Table 1), which extended the geographic and altitudinal distributional occurrence of Podonomus species in Brazil. Geographically, we increased the records of the genus far to the north region of southeastern Brazil. Regarding altitude, we increased the records from under $1300 \mathrm{~m}$ to above $2700 \mathrm{~m}$.

Although some Brazilian inselbergs are partly covered by conservation units, most such protected areas still lack specific conservation actions that would take into account the peculiarities of inselberg environments (Martinelli, 2007). We consider that the Podonomus species specificity to inselberg aquatic habitats, which are subject to anthropogenic impacts (e.g. trampling, organic pollution and invasion by exotic species), gives urgency to carrying out further studies and that information on this group should be included in a broad strategy for biodiversity conservation in Brazilian inselbergs.

Acknowledgements. This study received partial financial support from CAPES PNPD (23038.006958/2011-43), FAPESP (BIOTA 2007/56574-4) and KINROSS CABRNET. We would like to thank Dr Paul Hebert and the Canadian Centre for DNA Barcoding for supporting the barcoding studies. The authors also thank Dr Peter Cranston for his carefully revision of the manuscript. Rafaela Francisconi Gutierrez and Raquel Taminato helped in the fieldwork. The first, second and fourth authors received fellowships from CNPQ, CAPES and CNPQ, respectively.

\section{References}

Ashe P. and O'Connor J.P., 2009. A world catalogue of Chironomidae (Diptera). Part 1. Buchonomyiinae, Chilenomyiinae, Podonominae, Aphroteniinae, Tanypodinae, Usambaromyiinae, Diamesinae, Prodiamesinae and Telmatogetoninae. Irish Biogeographical Society and National Museum of Ireland, Dublin, 445 p.

Brundin L., 1966. Transantarctic relationships and their significance, as evidenced by chironomid midges with 

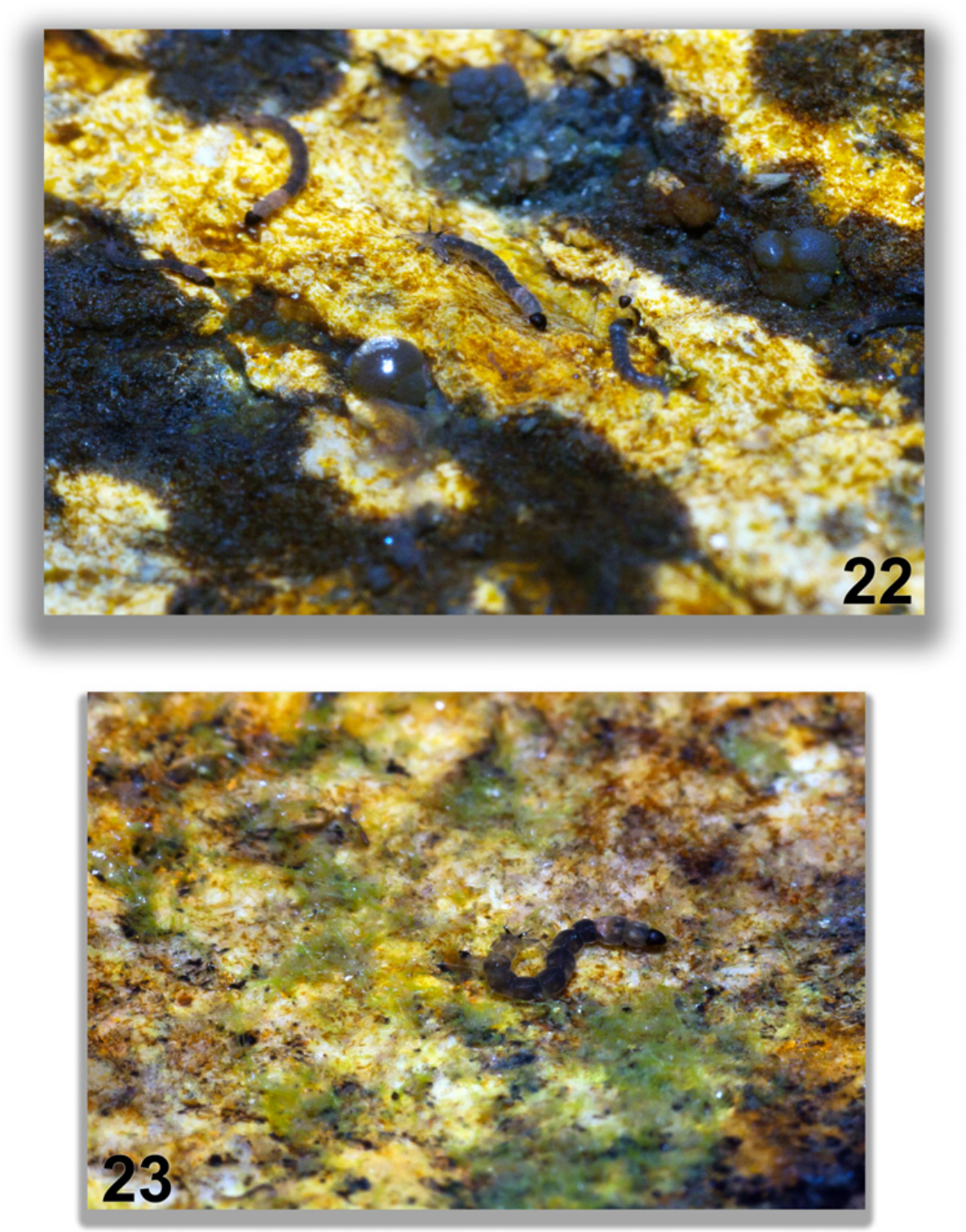

Figs. 22-23. $P$. pepinellii larva in situ, photographed in its natural habitat.

a monograph of the subfamilies Podonominae and Aphroteniinae and the austral Heptagyiae. Kunglica Svenska Vetenskapsakademiens Handlingar, 11, 1-472.

Cranston P.S., Hardy N.B., Morse G.E., Puslednik L. and McCluen S.R., 2010. When morphology and molecules concur: the 'Gondwanan' midges. (Diptera: Chironomidae). Syst. Entomol., 35, 636-648.

Ekrem T., Willassen E. and Stur E., 2007. A comprehensive DNA sequence library is essential for identification with DNA barcodes. Mol. Phylogenet. Evol., 43, 530-542.

Ekrem T., Stur E. and Hebert, P.D.N., 2010. Females do count: documenting Chironomidae (Diptera) species diversity using DNA barcoding. Org. Divers. Evol., 10, 397-408.

Hamada N., Pepinelli M., Mattos-Glória A. and Luz S.L.B., 2010. A new black fly species from Brazil, closely related to Simulium guianense Wise (Diptera, Simuliidae), revealed by morphology and DNA barcoding. Zootaxa, 2428, 22-36.
Hebert P.D.N., Penton E.H., Burns J.M., Janzen D.H. and Hallwachs W., 2004. Ten species in one: DNA barcoding reveals cryptic species in the neotropical skipper butterfly Astraptes fulgerator. Proc. Natl. Acad. Sci. USA, 101, 14812-14817.

Kimura M., 1980. A simple method for estimating evolutionary rates of base substitutions through comparative studies of nucleotide-sequences. J. Mol. Evol., 16, 111-120.

Laurindo F.S., Wiedenbrug S., Trivinho-Strixino S., Neubern C.S.O. and Pepinelli M., 2012. Two new species of Hudsonimyia Roback, 1979 (Diptera: Chironomidae: Tanypodinae) from neotropical region unveiled by DNA barcoding. J. Nat. Hist. (to be published on May 2012)

Martinelli G., 2007. Mountain biodiversity in Brazil. Rev. Bras. Bot., 30, 587-597.

Roque F.O. and Trivinho-Strixino S., 2004. Podonomus pepinellii n. sp., first record of the genus and subfamily from Brazil (Diptera: Chironomidae: Podonominae). Zootaxa, 689, 1-7. 
Sæther O.A., 1980. Glossary of chironomid morphology terminology (Diptera: Chironomidae). Ent. Scand., Suppl. 14, 1-51.

Siri A., Paggi A. and Donato M., 2009. Podonomus fastigians (Chironomidae: Podonominae): redescription of the adult male and female, the pupa, and description of the larva. Entomol. News, 120, 522-529.

Stur E. and Ekrem T., 2011. Exploring unknown life stages of Arctic Tanytarsini (Diptera: Chironomidae) with DNA barcoding. Zootaxa, 2743, 27-39.
Tamura K., Peterson D., Peterson N., Stecher G., Nei M. and Kumar S., 2011. MEGA5: molecular evolutionary genetics analysis using maximum likelihood, evolutionary distance, and maximum parsimony methods. Mol. Biol. Evol., 28, 2731-2739.

Wiedenbrug S., Mendes H.F., Pepinelli M. and TrivinhoStrixino S., 2009. Review of the genus Onconeura Andersen et Sæther (Diptera: Chironomidae), with the description of four new species from Brazil. Zootaxa 2265, 1-26. 